\title{
Kajian Geoteknik Untuk Desain Pit Tambang Batugamping Di Daerah Karang Dawa, Kecamatan Margasari, Kabupaten Tegal, Jawa Tengah
}

\author{
Mersi Abadi ${ }^{1}$, Arifudin Idrus ${ }^{1}$, I Gde Budi Irawan ${ }^{1}$ \\ 1Jurusan Teknik Geologi, Universitas Gadjah Mada
}

\begin{abstract}
Abstrak
Lokasi penelitian terletak di Desa Karangdawa, Kecamatan Margasari, Kabupaten Tegal, Jawa Tengah. Lokasi penelitian merupakan Wilayah Izin Usaha Pertambangan eksplorasi PT. Indocement Tunggal Prakarsa Tbk., dengan komoditas batugamping. Penelitian ini ditujukan untuk mengetahuikualitas, sumber daya dan cadangan batugampingserta model geoteknik berdasarkan model geologi. Model geoteknik juga ditentukan berdasarkan model rockmass yang digunakan sebagai model analisis kestabilan lereng untuk mendesain pit tambang. Metode yang digunakan dalam penelitian ini meliputi pekerjaan lapangan berupa pengamatan terhadap singkapan batuan dan pegambilan sampel, serta analisis laboratorium berupa analisis petrografi dan analisis XRF menggunakan sampel permukaan,analisis sifat fisik dan mekanik batuan, serta klasifikasi massa batuan berdasarkan Geological Strenght Index (GSI) menggunakan data sekunder berupa data inti pemboran. Analisis kestabilan lereng pada penelitian ini menggunakan metode kesetimbangan batas (limit equilibrium method). Interpretasi dan korelasi data inti pemboran menunjukkan bahwa lokasi penelitian secara stratigrafi tersusun oleh tiga satuan batuan yaitu :batugamping, batulempung, serta batupasir. Hasil analisis XRF dan pemodelan geologi menunjukkan kualitas batugamping memenuhi standar sebagai bahan baku semen dengan jumlah sumberdaya batugamping 13.180.000 ton. Geometri lereng yang dihasilkan dari analisis kestabilan lereng yaitu :tinggi lereng tunggal 10 meter, sudut kemiringan lereng tunggal 80 derajat, lereng overall 48 derajat, 50 derajat, 54 derajat, 60 derajat, lebar jenjang 8,31 meter. Estimasi cadangan batugamping ditentukan hanya berdasarkan pertimbangan desain pit tambang dan ultimate pit limit yang dibatasi oleh Wilayah IUP. Cadangan tertambang (mineable reserve) batugamping berjumlah 7.477.000 ton.
\end{abstract}

Katakunci : Geoteknik, desain tambang, cadangan, batugamping, Tegal.

\section{Pendahuluan}

Pada kegiatan industri pertambangan, isu yang seringkali menjadi perhatian besar bagi pemangku kepentinganadalah masalah keselamatan kerja operasional pertambangan, baik keselamatan pekerja maupun keselamatan alat dan sarana penunjang lainnya, yang bisa berakibat terhentinya kegiatan produksi atau penambangan. Salahsatu contoh adalah masalah kestabilan lereng tambang yang seringkali mengalami kelongsoran. Gonzales de Vallejo dan Ferrer (2011) menjelaskan faktor yang berpengaruh terhadap kestabilan lereng diantaranya yaitu :faktor geometri lereng, faktor geologi, faktor hidrogeologi, serta faktor geomekanik (kekuatan, deformabilitas dan permeabilitas batuan). Penelitian ini dilakukan untuk membuat desain pit tambang dan menghitung cadangan batugamping di daerah penelitian berdasarkan analisis kestabilan lereng dengan metode kesetimbangan batas dan klasifikasi massa batuan metode Geological Strength Index (GSI). Penelitian ini dilakukan di Daerah Karangdawa, Kecamatan Margasari, Kabupaten Tegal, Jawa Tengah.
*Korespodensi Penulis: (Mersi Abadi) Jurusan Teknik Geologi, Fakultas Teknik, Universitas Gadjah Mada. Kawasan Kampus Terpadu UGM, Yogyakarta.

Email:

\section{Geologi Regional}

Secara fisiografis daerah penelitian termasuk ke dalam zona Dataran Aluvial Jawa Utara(Van Bemmelen, 1949), dimana bagian utara berbatasan dengan laut Jawa, di bagian selatan berbatasan dengan zona Serayu Utara, di bagian barat berbatasan dengan zona Bogor, serta di bagian timur berbatasan dengan zona gunungapi kuarter. Menurut Djuri et al.,(1996) dalam peta geologi lembar Purwokerto dan Tegal, daerah penelitian berada padaAnggota Batugamping Formasi Tapakdan Endapan Lahar G. Slamet. Anggota Batugamping Formasi Tapak tersusun atas lensa-lensa batugamping tak berlapis yang berwarna kelabu kekuningan, formasi ini berumur berkisar antara Pliosen Awal - Miosen Akhir, sedangkan Endapan Lahar G. Slametterdiri dari lahar, dengan bongkahan batuan gunungapi bersusunan andesit-basal, bergaris tengah 10-50 cm dihasilkan oleh $\mathrm{G}$. Slamet Tua, sebarannya meliputi daerah datar dan berumur Holosen. 
Perlipatan di daerah ini umumnya mempengaruhi batuan Neogen Muda, dengan arah utama hampir barat-timur. Beberapa sumbu lipatan yang arahnya acak diduga merupakan lipatan seretan akibat sesar-sesar regional. Sesar utama berarah baratlaut - tenggara dan timurlaut baratdaya, dengan gerakan miring. Sesar lainnya berarah hampir utara-selatan atau barat-timur.
Sesar naik yang arahnya barat-timur, dimana bongkah utara nisbi bergerak naik, diduga sebagai bagian dari system sesar naik busur belakang. Berdasarkan pola sebaran sesar dan lipatannya, arah mampatan utama adalah utaraselatan.

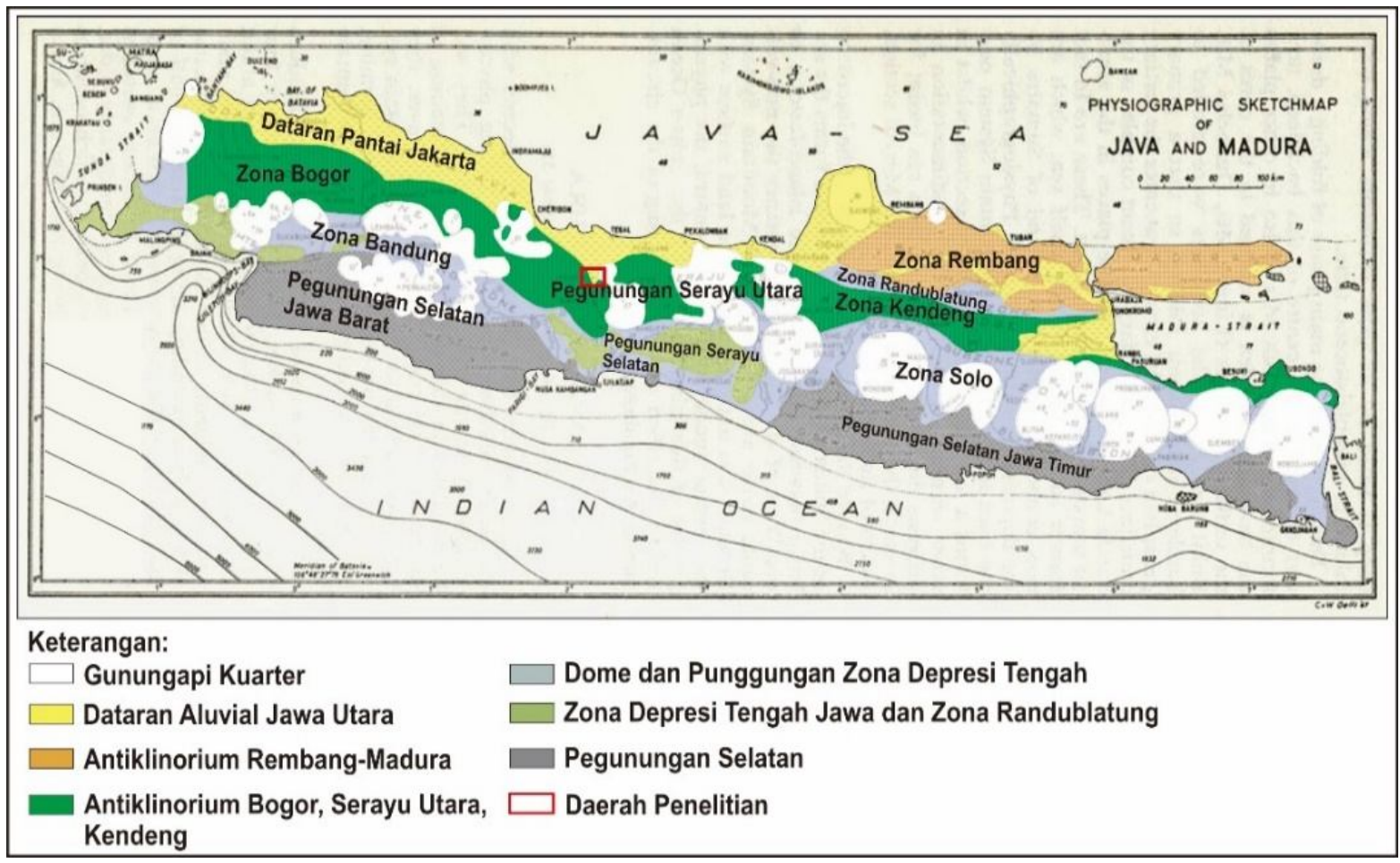

Gambar 2.1. Fisiografi Jawa Tengah (Van Bemmelen,1949).

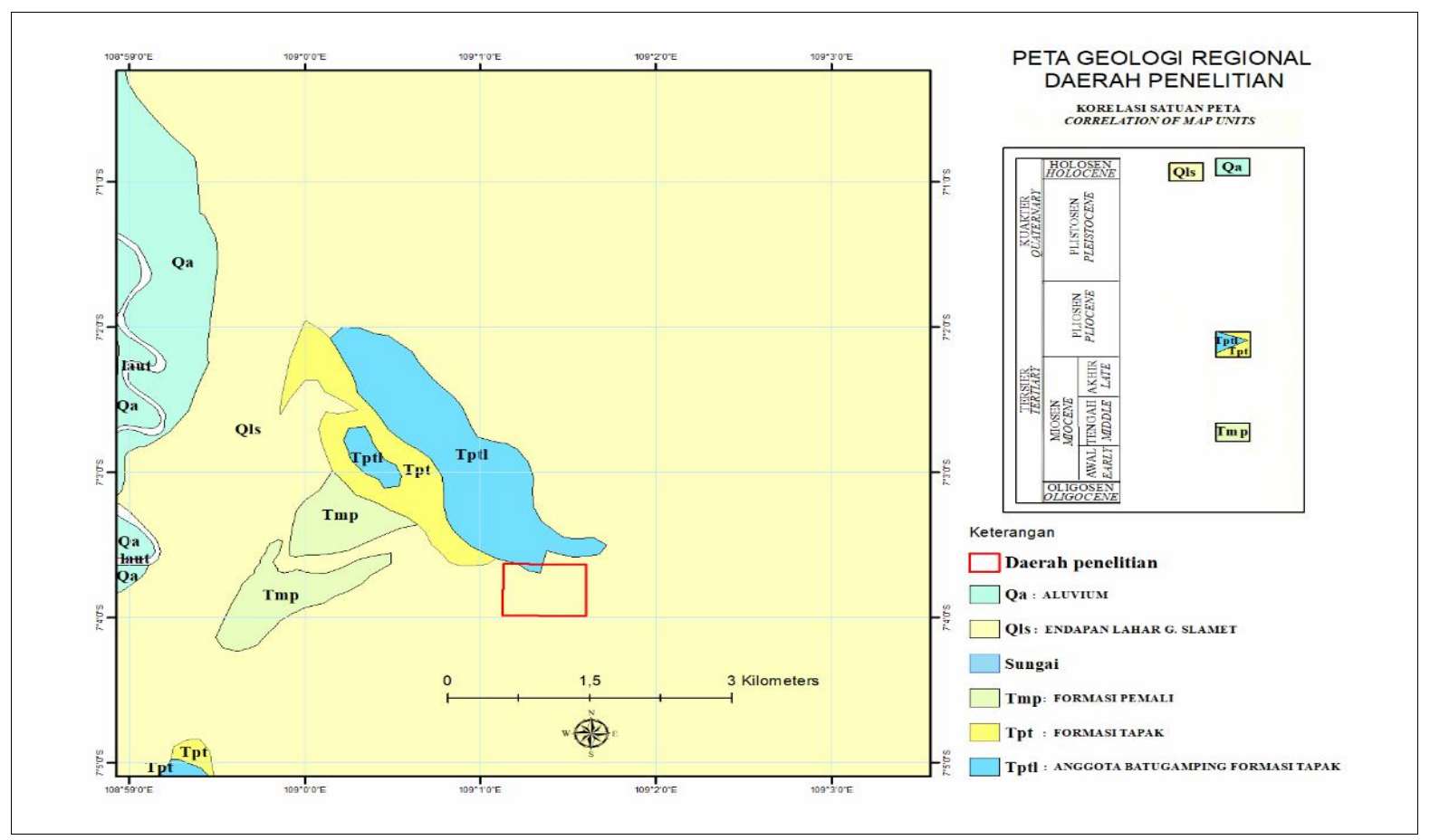

Gambar 2.2. Peta geologi regional daerah penelitian (Djuri et al.,1996) 


\section{Metode Penelitian}

\section{Studi Pendahuluan}

Langkah pertama dalam penelitian ini adalah melakukan studi pustaka dan survei tinjau. Pada studi pustaka melakukan analisis dan mempelajari data sekunder berupa geologi regional, data pemboran inti, serta sumber referensi yang berkaitan dengan topik penelitian, sedangkan pada survei tinjau melakukan survei pendahuluan lapangan yang bertujuan untuk mengetahui kondisi daerah penelitian secara umum.

\section{Kegiatan Lapangan}

Pada kegiatan ini dilakukan pengamatan dan pengambilan data mengenai informasi geologi secara langsung dilapangan berupa pengambilan titik koordinat, pengamatan litologi dan struktur geologi pada singkapan batuan, pengambilan sampel batuan permukaan serta pengambilan dokumentasi lapangan. Pengambilan sampel batuan permukaan dilakukan pada singkapan batuan berjumlah 10 titik di sekitar masingmasing titik bor.

\section{Uji Laboratorium}

1. Petrografi

Analisis petrografi dilakukan untuk menganalisa mineralogi berupa struktur dan tekstur batuan serta komposisi mineralnya yang digunakan untuk menentukan klasifikasi nama batuan dan model geologi. Analisis ini dimulai dengan membuat preparasi sampel batuan setangan berjumlah 10 sampel menjadi sayatan tipis (thin section) setebal 0,3 $\mathrm{mm}$, lalu kemudian dilakukan pengamatan menggunakan mikroskop polarisasi di Laboratorium Pusat Departemen Teknik Geologi Universitas Gadjah Mada.

2. X-Ray Fluorescence spectrometry (XRF)

Analisis XRF digunakan untuk menentukan unsur kimia utama (major element) dan unsur minor (minor element) pada sampel batuan. Pada penelitian ini analisis XRF dilakukan pada 10 sampel batuan setangan dan dianalisa di Laboratorium Pusat Survei Geologi, Badan Geologi, Bandung. Data hasil analisis ini selain untuk mengetahui kandungan unsur kimia di dalam batugamping, juga digunakan untuk mengetahui kualitas batugamping sebagai bahan baku semen.

3. Sifat Fisik dan Mekanik Batuan
Uji sifat fisik dan mekanik batuan dilakukan pada sampel data hasil pemboran inti (coring), data ini merupakan data sekunder. Untuk data sifat fisik batuan yang digunakan sebagai parameter input analisisi kestabilan lereng berupa saturatedunit weight. Sedangkan sifat mekanik batuan yaitu ; kuat tekan batuan (UCS), kohesi, serta sudut geser dalam. Pengujian tersebut dilakukan di laboratorium Geomekanika, Jurusan Teknik Pertambangan UPN Yogyakarta.

\section{Pengolahan Data}

\section{Model Geologi}

Tujuan pemodelan geologi adalah untuk menghitung sumberdaya dan cadangan batugamping, sertamodel geoteknik yang akan digunakan untuk analisis kestabilan lereng. Data yang perlukan dalam pembuatan model geologi antaralain yaitu :peta topografi, peta geologi, data pemboran berupa koordinat lokasi titik bordan jenis litologi. Pemodelaan geologi yang akan dibuat berupa model geologibawah permukaan dalam bentuktiga dimensi menggunakan Micromine 2016.

2. Model Rockmass

Model rockmass ditentukan berdasarkan data hasil analisis sifat fisik dan mekanik batuan berupa nilai saturated unit weight, Unconfined Compressive Strength (UCS), data analisis joint condition dari data core log, serta nilai Rock Quality Designation (RQD).

3. Model Geoteknik

Model geoteknik dibangun berdasarkan model geologi dan model rockkmass yang berisi informasi tentangdomain geoteknik berupa nilai GSI dan kelas massa batuan.

4. Analsis Kestabilan Lereng

Analisis kestabilan lereng dengan metode kesetimbangan batas akan dilakukan menggunakan software slide 6.0, dengan parameter berupa sifat fisik dan mekanik batuan berupa bobot isi (saturated unit weight),kohesi, serta sudut geser dalam.Tipe kekuatan batuan yang digunakan dalam analisis ini adalah generalized hook-brown. Menurut Wyllie dan Mah (2004), metode desain lereng batuan terbagi menjadi dua grup, yaitu analisis kesetimbangan batas dan analisis numerik. Metode kesetimbangan batas menghitung faktor keamanan pada suatu lereng dan prosedur yang berbeda digunakan untuk tipe longsoran yang berbeda. Nilai faktor keamanan yang dapat diterima pada penelitian ini adalah sebesar $F K \geq 1,5$. Fitur dasar dari semua metode desain lereng adalah gaya geser atau penggerak yang menempati di sepanjang permukaan bidang gelincir ataupun zona lemah didalam lereng batuannya. Jika gaya 
penggerak lebih besar daripada kuat geser batuan atau gaya penahan (resisiting force), maka lereng akan menjadi tidak stabil.

3. Desain Pit Tambang

Desain pit tambang ditentukan berdasarkan rekomendasi geometri hasil analisis kestabilan lereng menggunakan software Maptek Vulcan 9.0.2 Data geometri yang dihasilkan berupa sudut kemiringan dan tinggi lereng baik lereng tunggal (individual slope) maupun lereng keseluruhan (overall slope),kemudian setelah pit tambang terbentuk, akan dihitung jumlah cadangan tertambang berdasarkan batas akhir penambangan (ultimate pit limit), dikarenakan model atau parameter ekonomi tidak tersedia, sehingga di dalam penentuan batas akhir penambangnya menggunakan asumsi bahwa batas tersebut dibatasi oleh wilyah IUP dan sebaran daerah yang memiliki potensi yang dominan berdasarkan interpretasi data pemboran.

\section{Hasil dan Pembahasan}

\section{Geologi Daerah Penelitian}

\section{Litologi}

Secara regional geologi daerah penelitian termasuk ke dalam lembar peta Purwokerto \& Tegal yang berada pada dua formasi yaitu Formasi Tapak dan endapan lahar G. Slamet, dan berdasarkan databorehole lithology log, terdapattiga satuan litologi, secara berurutan dari tua ke muda yaitu satuan batupasir, batulempung, serta batugamping. Foto singkapan litologi batugamping yang terlihat di permukaan dapat dilihat pada gambar 4.1, sedangkan peta sebaran litologi daerah penelitian dapat dilihat pada gambar 4.2. Sayatan model geologi ditentukan berdasarkan data pemboran dan dibuat pada masing-masing titik bor hal ini diperlukan untuk melakukan analisis kestabilan lereng pada setiap titik bornya. Sayatan model geologi ini juga digunakan sebagai dasar untuk membangun model geoteknik.

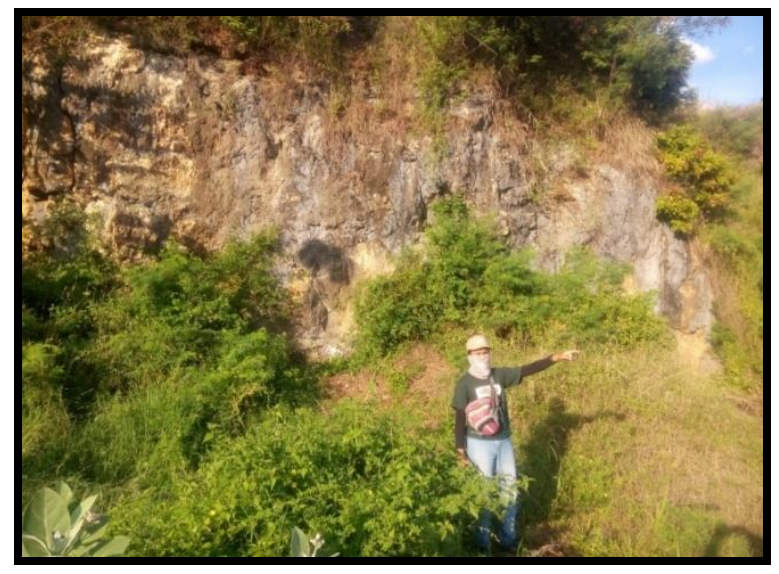

Gambar 4. 1 Singkapan litologi batugamping

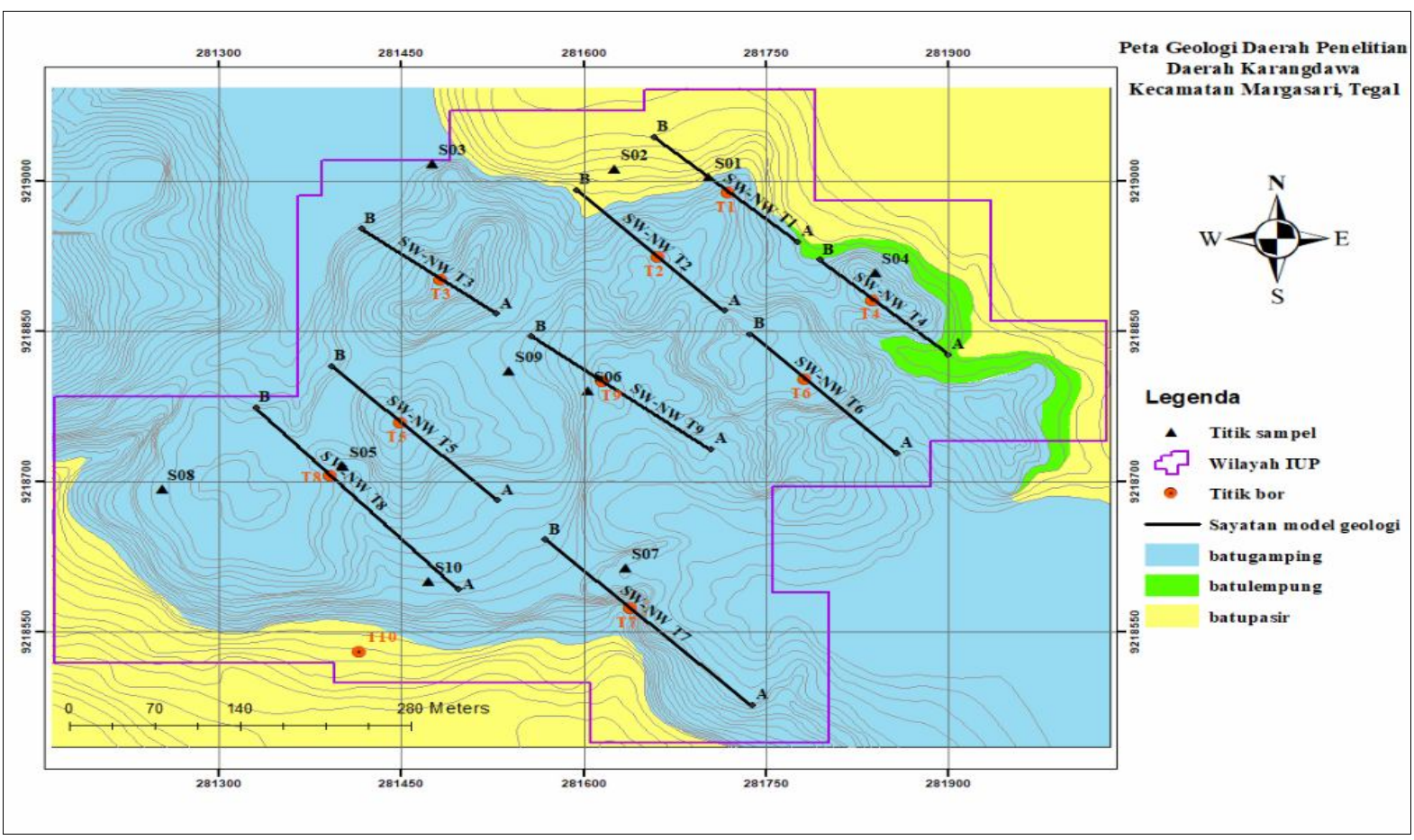

Gambar 4. 2 Peta geologi daerah penelitian 
Promine Journal, December 2018, Vol. 6 (2), page 5 - 15

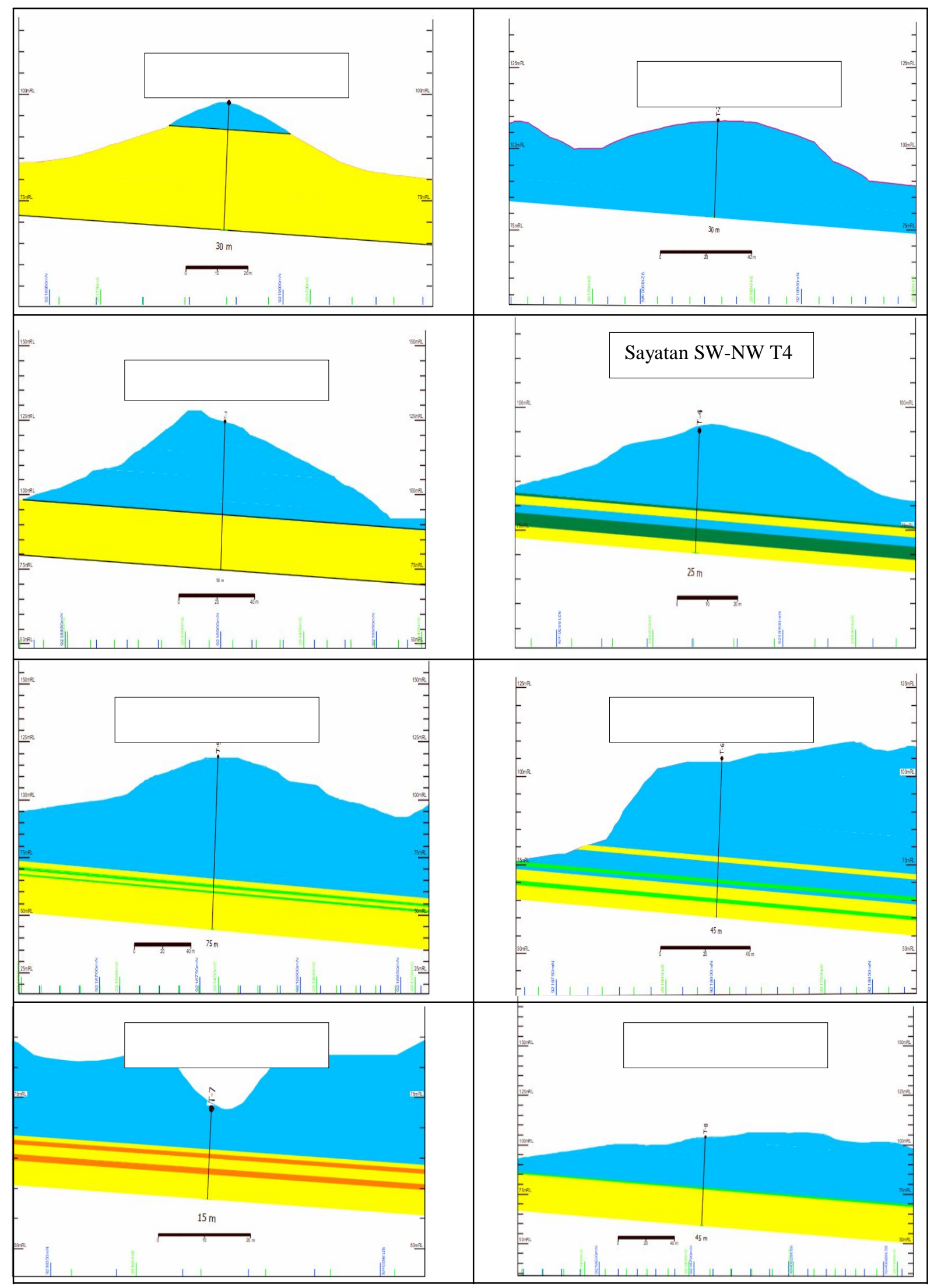




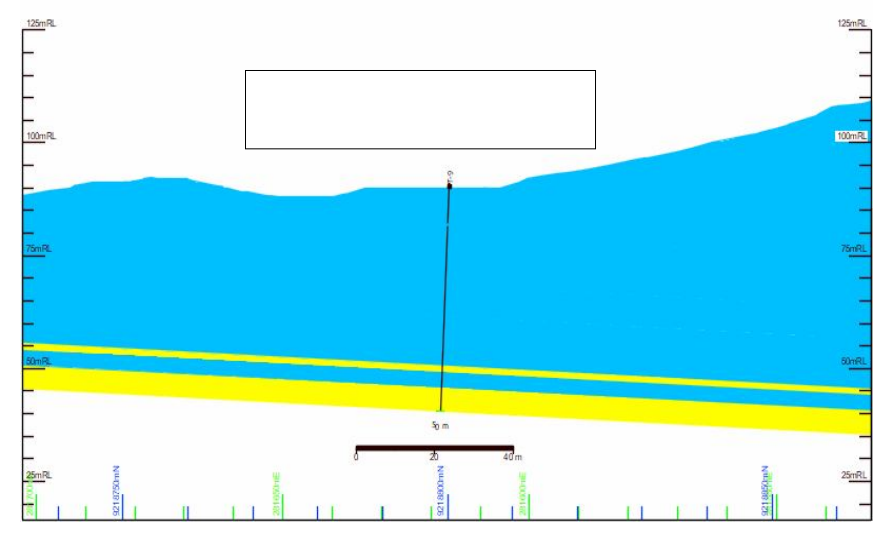

Gambar 4. 3 Gambar sayatan model geologi pada masing-masing titik bo

\section{Mineralogi}

Analisis petrografi dilakukan pada sampel permukaan berjumlah 10 titik yang berada pada satuan litologi batugamping. Berdasarkan hasil analisis tersebut dengan menggunakan klasifikasi Dunham (1962), didapat 3 jenis klasifikasi batugamping yaitu :mudstone, packstone, dan wackstone. Secara umum mineralogi dari satuan litologi batugamping mempunyai komposisi antaralain foram bentonik, mikrit, sparit, kalsit, serta terdapat rongga.Berdasarkan pengamatan petrografi secara keseluruhan batuan didominasi oleh kandungan sparit sehingga secara mineralogi jika dikaitkan dengan sifat keteknikan batuan masuk ke dalam kategotri batuan sparitic limestones yang mempunyai nilai konstanta batuan (mi) sebesar 10.

3. Geokimia Batuan

Analisis geokimia batuan metode XRF dilakukan di Laboratorium Pusat Survei Geologi Badan Geologi Bandung, dengan menganalisa 10 titik sampel batuan permukaan. Hasil analisis menghasilkan komposisi dan kandungan berupa senyawa dan unsur kimia yang terdapat dalam batuan (lihat tabel 5.1). Hasil analisis ini menunjukkan bahwa pada litologi satuan batugamping mengandung mineral atau material karbonat diatas $50 \%$, sehingga batuan tersebut termasuk kedalam batuan sedimen karbonat.

Tabel 4. 1 Rangkuman hasil analisis XRF

\begin{tabular}{lccccc}
\hline $\begin{array}{l}\text { Kode } \\
\text { sampel }\end{array}$ & $\begin{array}{c}\mathrm{CaO} \\
(\%)\end{array}$ & $\begin{array}{c}\mathrm{SiO}_{2} \\
(\%)\end{array}$ & $\begin{array}{c}\text { Senyawa } \\
\mathrm{Al}_{2} \mathrm{O}_{3} \\
(\%)\end{array}$ & $\begin{array}{c}\mathrm{Fe}_{2} \mathrm{O}_{3} \\
(\%)\end{array}$ & $\begin{array}{c}\mathrm{MgO} \\
(\%)\end{array}$ \\
\hline $\mathrm{S}-01$ & 54,56 & 0,682 & 0,315 & 0,39 & 0,853 \\
$\mathrm{~S}-02$ & 55,59 & 0,641 & 0,252 & 0,179 & 0,63 \\
$\mathrm{~S}-03$ & 54,82 & 0,992 & 0,385 & 0,183 & 0,826 \\
$\mathrm{~S}-04$ & 53,98 & 0,912 & 0,36 & 0,363 & 0,856 \\
$\mathrm{~S}-05$ & 55,36 & 0,557 & 0,243 & 0,182 & 0,582 \\
$\mathrm{~S}-06$ & 53,91 & 0,912 & 0,371 & 0,39 & 0,135 \\
$\mathrm{~S}-07$ & 51,98 & 1,96 & 0,823 & 0,43 & 1,96
\end{tabular}

\begin{tabular}{|c|c|c|c|c|c|}
\hline S-08 & 53,62 & 1,23 & 0,501 & 0,406 & 1,17 \\
\hline S-09 & 55,27 & 0,68 & 0,287 & 0,214 & 0,684 \\
\hline S-10 & 55,31 & 0,634 & 0,247 & 0,773 & 0,145 \\
\hline $\begin{array}{c}\text { Rata- } \\
\text { rata }\end{array}$ & 54,44 & 0,92 & 0,38 & 0,35 & 0,7841 \\
\hline
\end{tabular}

Tabel 4. 2 Perbandingan unsur kimia batugamping

\begin{tabular}{|c|c|c|c|}
\hline $\begin{array}{l}\text { Komposisi } \\
\text { kimia }\end{array}$ & $\begin{array}{l}\text { Hasil } \\
\text { analisis }\end{array}$ & $\begin{array}{c}\text { Standar } \\
\text { bahan baku } \\
\text { semen } \\
\text { Duda (1976) }\end{array}$ & $\begin{array}{c}\text { Standar bahan } \\
\text { baku semen } \\
\text { PT. Semen } \\
\text { Padang }\end{array}$ \\
\hline $\mathrm{CaO}$ & $54,44 \%$ & $49,8-55,6 \%$ & Minimum $48 \%$ \\
\hline $\mathrm{SiO}_{2}$ & $0,92 \%$ & $0,76-4,75 \%$ & Maksimum 5\% \\
\hline $\mathrm{Al}_{2} \mathrm{O}_{3}$ & $0,38 \%$ & $0,71-2,00 \%$ & $\begin{array}{c}\text { Maksimum } \\
0,95 \%\end{array}$ \\
\hline $\mathrm{Fe}_{2} \mathrm{O}_{3}$ & $0,35 \%$ & $0,36-1,47 \%$ & $\begin{array}{c}\text { Maksimum } \\
2,47 \%\end{array}$ \\
\hline $\mathrm{MgO}$ & $0,78 \%$ & $0,30-1,48 \%$ & Maksimum 5\% \\
\hline
\end{tabular}

Tujuan dari analisis ini adalah untuk mengetahui kualitas batugamping sebagai bahan baku utama semen. Kualitas batugamping dapat dilihat dari kandungan senyawa $\mathrm{CaO}$, batugampung dikatakan sangat baik digunakan untuk bahan baku semen jika kandungan $\mathrm{CaO}$ lebih dari 50\% (Santika and Mulyadi, 2017). Carter (1958) dan Misnandar (1981) menyatakan bahwa kadar $\mathrm{CaO}$ untuk standar semen Portland adalah sebesar $64-65.5 \%$, sedangkan pabrik semen Indonesia pada umumnya seperti pabrik semen Gresik dan pabrik semen. Baturaja mempunyai ketentuan kadar $\mathrm{CaO}$ adalah $50 \%$ $55 \%$, dan kadar maksimum $\mathrm{MgO} 2 \%, \mathrm{FeO}_{3}$ $2,47 \%, \quad \mathrm{Al}_{2} \mathrm{O}_{3} 0,95 \%$ (Adipura, 1977 dalam Santika dan Mulyadi, 2017). Hasil analisis komposisi kimia batugamping pada penelitian ini yang berupa $\mathrm{CaO}, \mathrm{SiO}_{2}, \mathrm{Al}_{2} \mathrm{O}_{3}, \mathrm{Fe}_{2} \mathrm{O}_{3}, \mathrm{MgO}$ akan dibandingkan dengan standar bahan baku semen menurut Duda (1976) dalam Widiarso et al.,(2017) terhadap standar bahan baku semen PT. Semen Padang (Widiarso et al., 2017), hasilnya dapat dilihat pada tabel 5.2. 
Berdasarkan perbandingan unsur kimia tersebut, bahwa jumlah rata-rata kandungan komposisi kimia batugamping pada penelitian ini memenuhi syarat sebagai bahan baku semen jika dikomparasi baik terhadap standar bahan baku semen menurut Duda (1976) maupun standar bahan baku semen PT Semen Padang.

\section{Model Geologi}

Pemodelan geologi dilakukan menggunakan perangkat lunak Micromine 2016 di Laboratorium Bahan Galian, Departemen Teknik Geologi, Universitas Gadjah Mada. Tujuan dari pemodelan geologi adalah untuk mengetahui kondisi geologi bawah permukaan baik 2 dimensi maupun 3 dimensi berdasarkan data dari masing-masing lubang bor. Keluaran dari pemodelan ini berupa model solid, selanjutnya darimodel solid tersebut dapat dihitung volume padatan dari satuan litologi yang ingin diketahui, dalam hal ini adalah volume atau sumberdaya batugamping yang merupakan salah satu komoditas tambang yang ekonomis dalam jumlah tertentu. Gambar 5.17 memperlihatkan model geologi dalam bentuk solid model dari tiga satuan litologi yang secara berurutan dari yang paling atas terdiri dari satuan litologi batugamping, satuan litologi batulempung, dan satuan litologi batupasir. Model geologi yang dihasilkan juga akan digunakan sebagai parameter data untuk membuat model geoteknik dalam pekerjaan analisis kestabilan lereng. Volume atau sumberdaya batugamping yang dapat dihitung dari hasil pembuatan model geologi atau solid model menggunakan software micromine yaitu sebesar 13.180.933 ton (tabel 4.3).
Tabel 4.3 Sumberdaya batugamping

\begin{tabular}{|c|c|c|c|c|c|}
\hline & WF TYPE & WF_NAME & VOLUME & TONNAGE & COMMENT \\
\hline 1 & Rock Model Limestone & 5730840.45 & 13180933.04 \\
2 & Rock Model & SUB-TOTAL & 5730840.45 & 13180933.04 & \\
\hline 3 & ALL & TOTAL & 5730840.45 & 13180933.04 \\
\hline
\end{tabular}

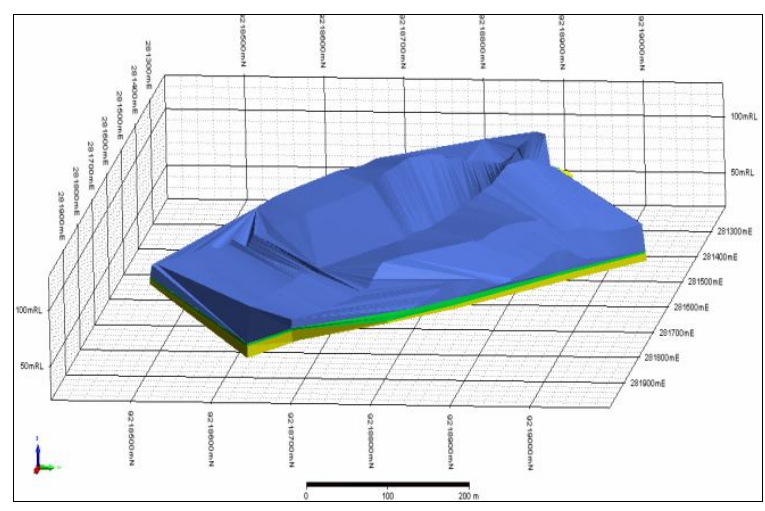

Gambar 4.4 Model geologi atau solid model dari tiga satuan litologi

\section{Model Rockmass}

Klasifikasi massa batuan yang digunakan adalah klasifikasi Geological Strength Index (GSI) yang merupakan klasifikasi massa batuan yang digunakan untuk mengestimasi kekuatan massa batuan pada kondisi geologi yang berbeda melalui deskripsi batuan inti.Pengklasifikasian massa batuan dilakukan pada 10 titik bor berdasarkan dua parameter, yaitu joint condition (Bieniawski, 1989) dan Rock Quality Designation (Deere, 1963). Pemberian parameter kekuatan massa batuan dilakukan berdasarkan deskripsi log pemboran dan dicocokkan dengan foto batuan inti.Model rockmass yang dihasilkan menunjukkan bahwa batuan termasuk dalam kategori poor rock good rock.

Tabel 4. 4 Model rock mass pada titik bor T4

\begin{tabular}{|c|c|c|c|c|c|c|c|c|c|c|c|c|c|c|c|c|c|c|}
\hline \multirow{2}{*}{\multicolumn{2}{|c|}{ Depth (m) }} & \multirow{2}{*}{ Lithology } & \multicolumn{8}{|c|}{$\begin{array}{l}\text { Joint Condition (Bieniawski, 1989) } \\
\text { B }\end{array}$} & \multirow{3}{*}{$\begin{array}{c}\text { RQD } \\
\text { Core length }(210 \mathrm{~cm}) \\
0\end{array}$} & \multirow{2}{*}{\begin{tabular}{|c|} 
GSI \\
$1,5 \mathrm{Jc}$ ond $+\mathrm{RQD} / 2$ \\
\end{tabular}} & \multirow{2}{*}{ GSI $_{\text {model }}$} & \multirow{2}{*}{ Sample } & \multirow{2}{*}{ Remarks } & \multirow{3}{*}{$\begin{array}{l}\text { Sat. Unit } \\
\text { Weight } \\
(\mathrm{kN} / \mathrm{m} 2) \\
\end{array}$} & \multirow{2}{*}{ 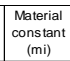 } & \multirow{2}{*}{ UCS (MPa } \\
\hline & & & Condition & Rating & Persistence (m) & & & Gouge & J Weathering & Rating & & & & & & & & \\
\hline 0 & 1 & Soil & $\mathrm{x}$ & & $x$ & $x$ & $x$ & $\mathrm{x}$ & $x$ & & & & 0 & & & & & \\
\hline & 1.5 & & & & $x$ & $x$ & $x$ & $x$ & $x$ & & 0 & 0 & \multirow{18}{*}{50} & & & & & \multirow{18}{*}{65.45} \\
\hline 1.5 & $\frac{2}{2}$ & $\begin{array}{l}\text { Fresh calcarenite } \\
\end{array}$ & VR & 30 & $x^{x}$ & $x^{x}$ & $x^{x}$ & 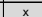 & $x$ & & $\frac{10}{10}$ & 50 & & & & \multirow{17}{*}{24.39} & \multirow{17}{*}{10} & \\
\hline 2 & 3 & & VR & 30 & $x$ & $x$ & $x$ & $x$ & $x$ & & 80 & 85 & & & & & & \\
\hline$\frac{2}{3}$ & $\frac{5}{4}$ & & VR & 30 & $\frac{1}{x}$ & $\frac{1}{x}$ & $\frac{1}{x}$ & $\frac{\hat{x}}{x}$ & $\frac{1}{x}$ & & 60 & 75 & & UCS & & & & \\
\hline 4 & 4.71 & Cave & $x$ & & $x$ & $x$ & $\frac{x}{x}$ & 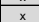 & $\frac{x}{x}$ & $x$ & $x$ & $x$ & & & & & & \\
\hline 4.71 & 5 & Fresh calcarenite & VR & 30 & $\frac{2}{x}$ & $x$ & $x$ & $x$ & $x$ & & 15 & 52.5 & & & & & & \\
\hline 5 & 6 & & $\begin{array}{ll}R \\
\end{array}$ & 30 & $x$ & $x$ & $\bar{x}$ & $x$ & $x$ & - & 10 & 50 & & & & & & \\
\hline 6 & 7 & & VR & 30 & 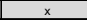 & $x$ & $x$ & $x$ & $x$ & & 20 & 55 & & & & & & \\
\hline 7 & 8 & Coreloss & $x$ & & $x$ & $x$ & $x$ & $x$ & $x$ & $x$ & $x$ & $x$ & & & & & & \\
\hline 8 & 8.5 & & $x$ & & $x$ & $x$ & $x$ & $x$ & $\mathrm{x}$ & $\mathrm{x}$ & $\mathrm{x}$ & $x$ & & & & & & \\
\hline 8.5 & 9 & Fresh calcarenite & VR & 30 & $x$ & $x$ & $x$ & $x$ & $x$ & & 10 & 50 & & & & & & \\
\hline 9 & 10 & Cave & $x$ & & $x$ & $x$ & $x$ & $x$ & $x$ & $x$ & $x$ & $x$ & & & & & & \\
\hline 10 & 11 & & $x$ & 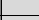 & $x$ & $x$ & $x$ & $x$ & $x$ & $x$ & $x$ & $x$ & & & & & & \\
\hline 11 & 11.5 . & torar & $x$ & & $x$ & $x$ & $x$ & $x$ & $x$ & $x$ & $x$ & $x$ & & & & & & \\
\hline 111.5 & 12 & Fresh calcarentite & VR & 30 & $x$ & $x$ & $\mathrm{x}$ & $x$ & $\mathrm{x}$ & & 10 & 50 & & & & & & \\
\hline 12 & 13 & & $V_{R}$ & 30 & $x$ & $x^{x}, y_{1}$ & $x$ & $x$ & $x$ & & 65 & 77.5 & & & & & & \\
\hline$\frac{13}{14}$ & 144 & & $V_{R}$ & 30 & $x$ & $x^{x}, y_{1}$ & $x^{x}, y_{1}$ & $x$ & $x$ & & 10 & 50 & & & & & & \\
\hline \begin{tabular}{|l|}
14 \\
15
\end{tabular} & $\left|\frac{15}{15.79}\right|$ & & $\frac{V R}{V R}$ & 30 & $\frac{x}{x}$ & $\frac{x}{x}$ & $\frac{x}{x}$ & $\frac{x}{x}$ & $\frac{x}{x}$ & & $\frac{20}{40}$ & $\frac{55}{65}$ & & & & & & \\
\hline 15.79 & 16 & S. Weathered clays tone & SR & 20 & $x$ & $x$ & $x$ & $x$ & $x$ & & 0 & 30 & \multirow[t]{3}{*}{30} & & $\mathrm{NRZ}$ & \multirow{3}{*}{19.02} & \multirow{3}{*}{2} & \multirow{5}{*}{$\begin{array}{l}2.95 \\
37.03\end{array}$} \\
\hline 16 & 16.4 & & SR & 20 & $x$ & $x$ & $x$ & $x$ & $x$ & & 25 & 42.5 & & & & & & \\
\hline 16.4 & 17 & $\begin{array}{l}\text { Fresh sandstone infliled calche } \\
\end{array}$ & $x$ & & $>20$ & $\frac{25}{>5}$ & $\begin{array}{ll}R \\
\end{array}$ & $<5$ & $F$ & 16 & 10 & 29 & & & & & & \\
\hline 17 & 17.5 & Coreloss & $x$ & ב & $x$ & $x$ & $x$ & $x$ & $x$ & $x$ & $x$ & $x$ & 24 & 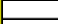 & ( & 22.29 & 17 & \\
\hline 17.5 & 17.9 & $\begin{array}{l}\text { Fresh sandstone infilled calche } \\
\end{array}$ & $x$ & 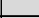 & $>20$ & $>5$ & VR & $<5$ & $\mathrm{~F}$ & 16 & 0 & 24 & & & NRZ & & & \\
\hline 15 & 18 & Fresh calcarentit infilled iron oxide & $x$ & 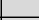 & $>20$ & 25 & VR & $<5$ & $\mathrm{~F}$ & 16 & 10 & 29 & & & & & & \\
\hline 18 & 18.15 & & $x$ & & $>20$ & $>5$ & VR & $<5$ & $\mathrm{~F}$ & 16 & 0 & 24 & & & NRZ & & & \\
\hline 18.15 & 18.7 & S. Weathered sandstone & SR & 25 & $x$ & & & $x$ & $x$ & & 0 & 37.5 & 32 & & NRZ & 24.39 & 10 & 65.45 \\
\hline | 18.7 & 19 & Fresh calcarentite infilled iron oxide & $x$ & & $>20$ & $\geq 5$ & VR & -5 & $\mathrm{~F}$ & 16 & 30 & 39 & & & & & & \\
\hline 19 & 20 & Coreloss & $x$ & & $x$ & $x$ & $x$ & $x$ & $x$ & $x$ & $x$ & $x$ & & & & & & \\
\hline 20 & 21 & M. Weathered claystone & $\mathrm{SR}$ & 20 & $\mathrm{x}$ & $x$ & $x$ & $x$ & $\mathrm{x}$ & & 0 & 30 & & & $\mathrm{NNZZ}_{2}$ & & & \\
\hline 21 & 21.5 & & $S R$ & 20 & $x$ & 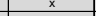 & $x^{x}, y_{1}$ & $x$ & $x$ & & 0 & 30 & 30 & & NHZ & 19.02 & 2 & 2.95 \\
\hline$\frac{21.5}{12 .}$ & 22 & Coreloss & $x$ & & $x$ & $x$ & $x$ & $x$ & $x$ & $x$ & $x$ & $x$ & & & & & & \\
\hline 22 & 22.5 & 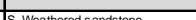 & $x$ & & $x$ & $x$ & $x$ & $x$ & $x$ & & $x$ & $x$ & & & 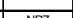 & & & \\
\hline$\frac{22.5}{203}$ & 23 & S. Weathered sandstone & $\frac{S R}{S R}$ & 25 & $x$ & 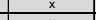 & $x$ & $x$ & $x$ & & 0 & 37.5 & & & NRZ & & & \\
\hline 年3 & 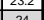 & Fareless & $\mathrm{sm}$ & 23 & $x$ & $x$ & $x$ & $x$ & $x$ & 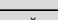 & $\pi$ & 42.5 & 42 & & & 2329 & 13 & 3703 \\
\hline \begin{tabular}{|l|l|l}
24 \\
\end{tabular} & 24.6 & & $x$ & & $x$ & $x$ & $\mathrm{x}$ & $\frac{2}{x}$ & $\frac{1}{x}$ & $\mathrm{x}$ & $\frac{1}{x}$ & $\frac{x}{x}$ & & & & & & \\
\hline 24.6 & 25 & Fresh sandstone & VR & 30 & $x$ & $x$ & $x$ & $\mathrm{x}$ & $x$ & & 0 & 45 & & & NFZ & & & \\
\hline
\end{tabular}




\section{Model Geoteknik}

Model geoteknik dibangun dari model geologi dan model rockmass. Model geologi memberikan informasi mengenai kondisi geologi berupa struktur geologi dan satuan litologi, sedangkan model rockmass memberikan informasi mengenai kekuatan massa batuan berdasarkan analisis dan perhitungan sifat fisik dan mekanik batuan dengan metode klasifikasi massa batuan tertentu, dalam penelitian ini digunakan klasifikasi metode Geological Strength
Index (GSI). Pada model geoteknik menunjukkan domain geoteknik yang memberikan informasi mengenai nilai GSI, klasifikasi serta peringkat kualitas massa batuan menggunakan Rock Mass Rating dari Bieniawski (1989). Model geoteknik ini kemudian digunakan sebagai model dalam analisis kestabilan lereng menggunakan software SLIDE 6.0.Secara keseluruhan model geoteknik yang didapat mempunyai nilai GSI sebesar 24 85 dengan peringkat RMR kelas II - IV.

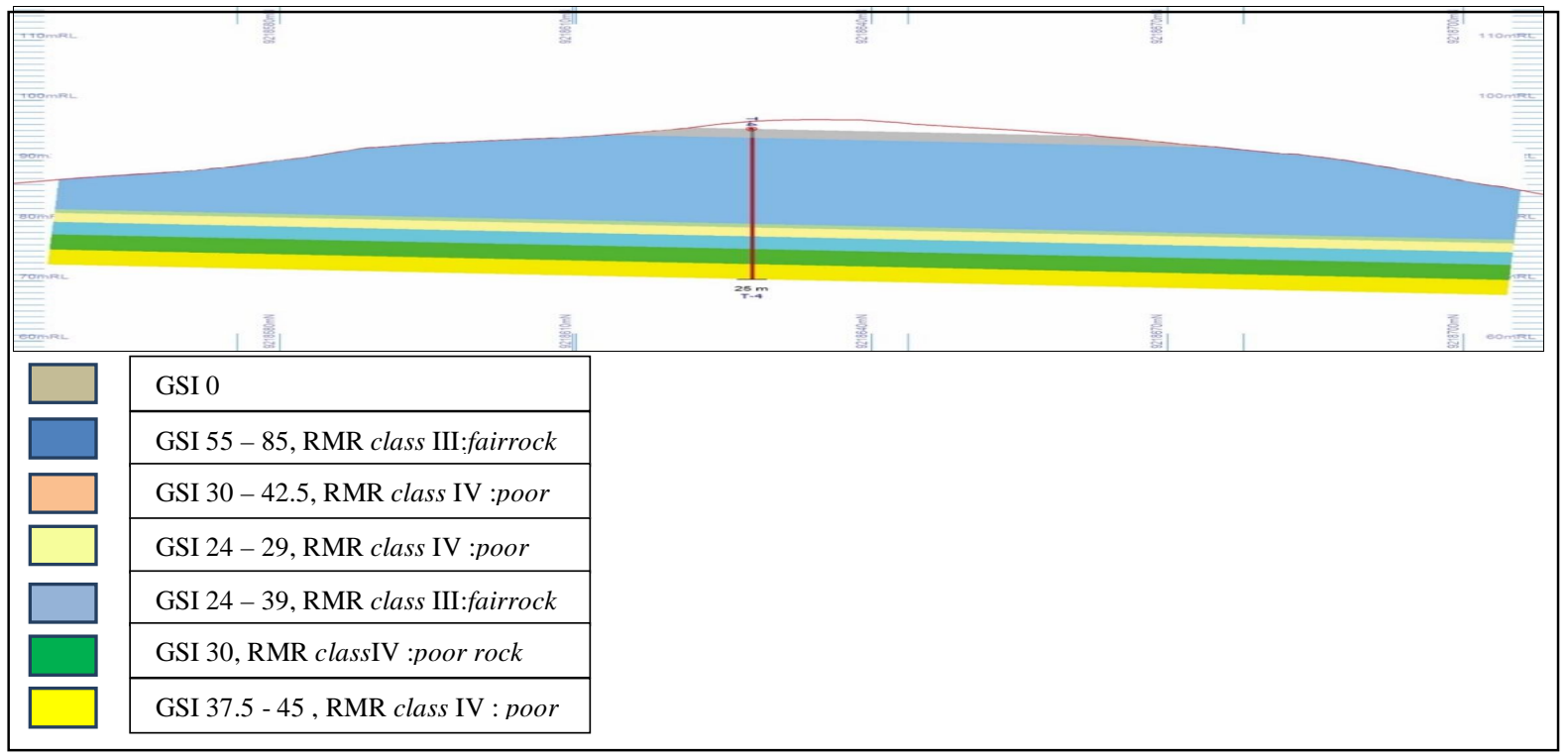

Gambar 4. 5 Model geoteknik pada titi bor T4

\section{Analisis Kestabilan Lereng}

Analisis kestabilan lereng dilakukan pada sembilan penampang titik bor, pada masingmasing titik bor dilakukan simulasi sebanyak tiga model geometri dengan tnggi lereng yang sama yaitu 10 meter, serta lebar jenjang dan sudut kemiringan lereng tunggal yang berbeda (tabel 5.8). Input parameter data analisis pada software SLIDE diantaranya yaitu :unit weight, cohesion, phi, UCS, nilai konstanta (s, m, dan a) serta nilai GSI. Nilai Faktor Keamanan (FK) yang diambil adalah nilai terkecil yangmasih aman atau nilai
$F K \geq 1,5$ dengan sudut kemeringan lereng yang paling terjal. Rekapitulasi nilai FK pada masingmasing titik bor dapat dilihat pada tabel 5.10. Hasil simulasi dari sembilan penampang titik bor memperlihatkan bahwa untuk sudut kemiringan lereng yang paling terjal yaitu 80 derajat masih mendapatkan nilai $\mathrm{FK}$ yang relatif aman, sehingga rekomendasi geometri lereng yang akan digunakan untuk menentukan desain pit tambangyaitu :sudut lereng tunggal 80 derajat, tinggi jenjang 10 meter, lebar jenjang 8.13 meter, overall slope 54 derajat.

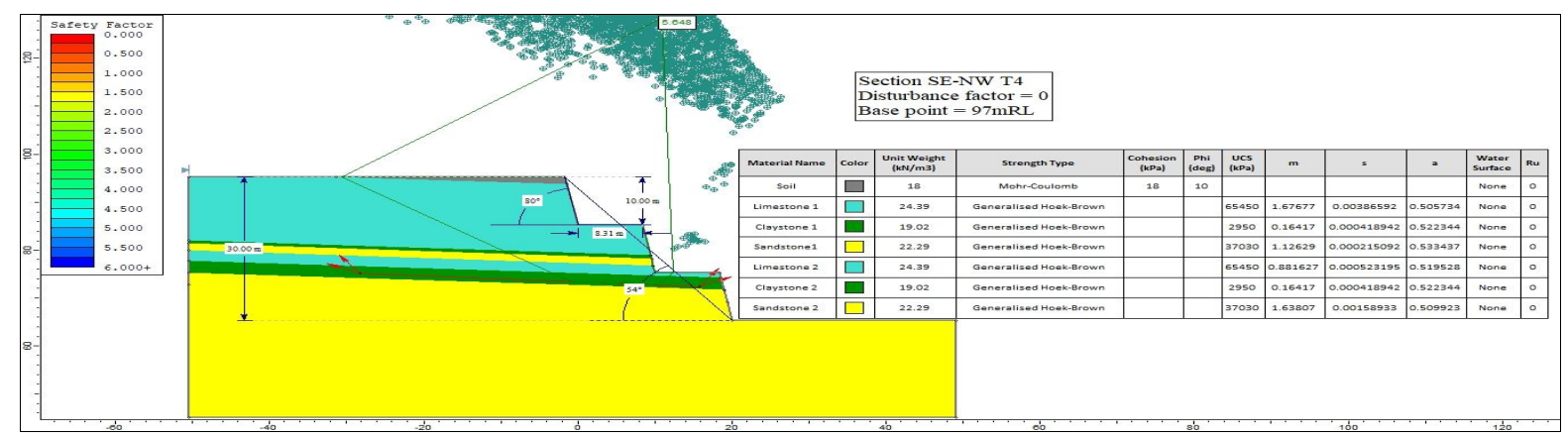

Gambar 4. 6 Model analisis kestabilan lereng pada titi bor T4 
Tabel 4. 5 Model geometri analisis kestabilan lereng

\begin{tabular}{|c|c|c|c|}
\hline Model & $\begin{array}{c}\text { Tinggi lereng } \\
\text { tunggal }\end{array}$ & Lebar jenjang & Sudut lereng \\
\hline 1 & 10 meter & 4.33 meter & 60 derajat \\
\hline & & & \\
\hline 2 & 10 meter & 6.45 meter & 70 derajat \\
\hline & & & \\
\hline 3 & 10 meter & 8.31 meter & 70 derajat \\
\hline
\end{tabular}

Tabel 4. 6 Rekapitulasi hasil analisis kestabilan lereng

\begin{tabular}{|c|c|c|c|c|c|}
\hline No & Titik bor & $\begin{array}{c}\text { Tinggi jenjang } \\
\text { tunggal }\end{array}$ & $\begin{array}{c}\text { Kemiringan } \\
\text { jenjang tunggal }\end{array}$ & Lebar jenjang & $\begin{array}{c}\text { Faktor } \\
\text { Keamanan }\end{array}$ \\
\hline 1 & T5 & 10 & 80 & 8.31 & 1.785 \\
\hline 2 & T6 & 10 & 80 & 8.31 & 2.431 \\
\hline 3 & T7 & 10 & 80 & 8.31 & 3.065 \\
\hline 4 & T8 & 10 & 80 & 8.31 & 3.100 \\
\hline 5 & T9 & 10 & 80 & 8.31 & 4.219 \\
\hline 6 & T3 & 10 & 80 & 8.31 & 4.343 \\
\hline 7 & T2 & 10 & 80 & 8.31 & 4.450 \\
\hline 8 & T4 & 10 & 80 & 8.31 & 5.648 \\
\hline 9 & T1 & 10 & 80 & 8.31 & 6.755 \\
\hline
\end{tabular}

\section{Desain Tambang}

Pada penelitian ini pembuatan desaintambang terbatas hanya sampai pada penentuan batas akhir penambangan (ultimate pit limit), dikarnakan tidak ada data parameter ekonomi, sehinggapenentuan ultimate pit limit berdasarkan pada batas wilayah IUP PT. Indocement, kemudian dari ultimate pit limit ini akan dibuat pit tambang yang menghasilkan keluaran berupa volume material yang tergali dan cadangan tertambang (mineable reserve). Proses pembuatan desain pit tambang menggunakan software Vulcan 9.0.2. Bentuk akhir dari desain pit tambang dapat dilihat pada gambar 4.4.

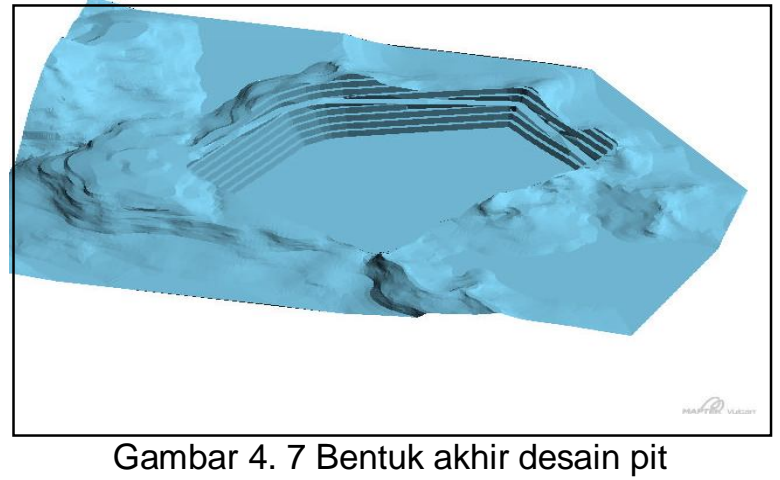

\section{Estimasi Cadangan}

Estimasi cadangan dapat diketahui berdasarkan pit tambang yang telah terbentuk dan dihitung dengan menggunakansoftware Vulcan9.0.2. Jumlah cadangan yang bisa ditambang, dihitung berdasarkan model cadangan di setiap kemajuan tambang per elevasinya, pada penelitian ini kemajuan penambangannya sesuai dengan tinggi jenjangnya yaitu per 10 meter. Berdasarkan model cadangan dan bentuk topografinya, penambangan dapat dimulai pada elevasi tertinggi 120 meter sampai kedalaman elevasi 40 meter. Model cadangan yang bisa ditambang dapat dilihat pada gambar 4.5 dan 4.6dengan rekapitulasi volume dan tonasenya dapat dilihat pada tabel 4.6.

Tabel 4. 7 Cadangan batugamping

\begin{tabular}{cccc}
\hline NO & $\begin{array}{c}\text { ELEVASI } \\
(\mathbf{m})\end{array}$ & $\begin{array}{c}\text { VOLUME } \\
\text { CADANGAN }\left(\mathbf{m}^{3}\right)\end{array}$ & $\begin{array}{c}\text { TONASE } \\
\text { CADANGAN } \\
\text { (ton) }\end{array}$ \\
\hline 1 & 40 & $5.048,55$ & $12.621,38$ \\
2 & 50 & $135.743,52$ & $339.358,80$ \\
3 & 60 & $476.173,97$ & $1.190 .434,91$ \\
4 & 70 & $732.850,61$ & $1.832 .126,52$ \\
5 & 80 & 778145,190 & $1.945 .362,98$ \\
6 & 90 & $597.605,51$ & $1.494 .013,77$ \\
7 & 100 & $224.579,34$ & $561.448,35$ \\
8 & 110 & $38.451,22$ & $96.128,05$ \\
9 & 120 & $2.242,59$ & $5.606,46$ \\
& & 2.990 .000 & 7.477 .000 \\
\hline
\end{tabular}

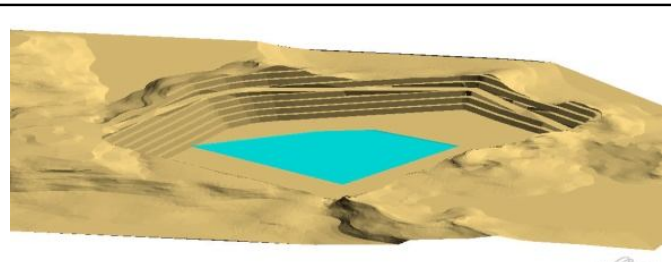

Elevasi $50 \mathrm{dpl}$ 


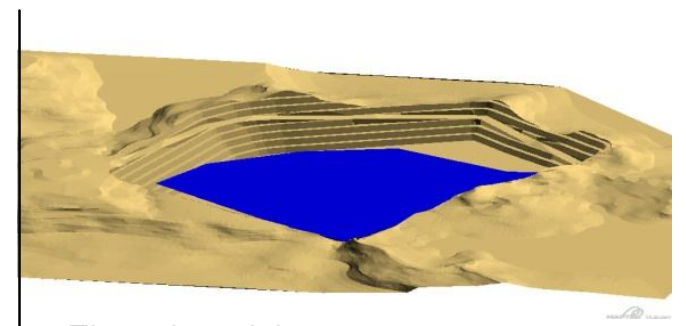

Elevasi $60 \mathrm{dpl}$

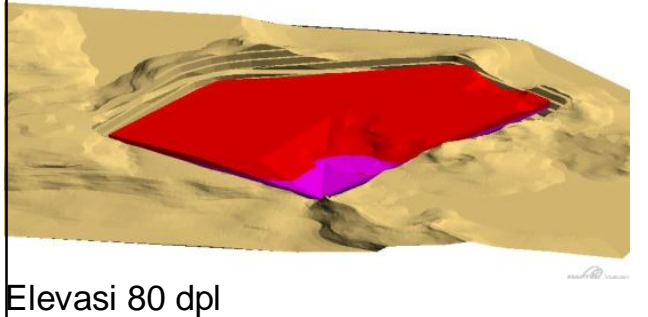

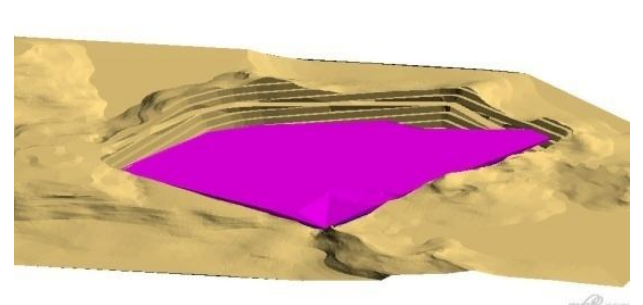

Elevasi $70 \mathrm{dpl}$

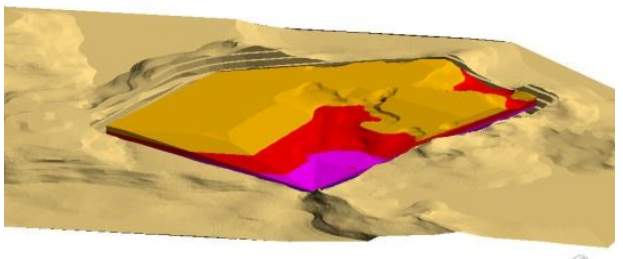

Elevasi $90 \mathrm{dpl}$

Gambar 4. 8 Model cadangan batugamping pada elevasi $40 \mathrm{dpl}$ sampai $90 \mathrm{dpl}$.

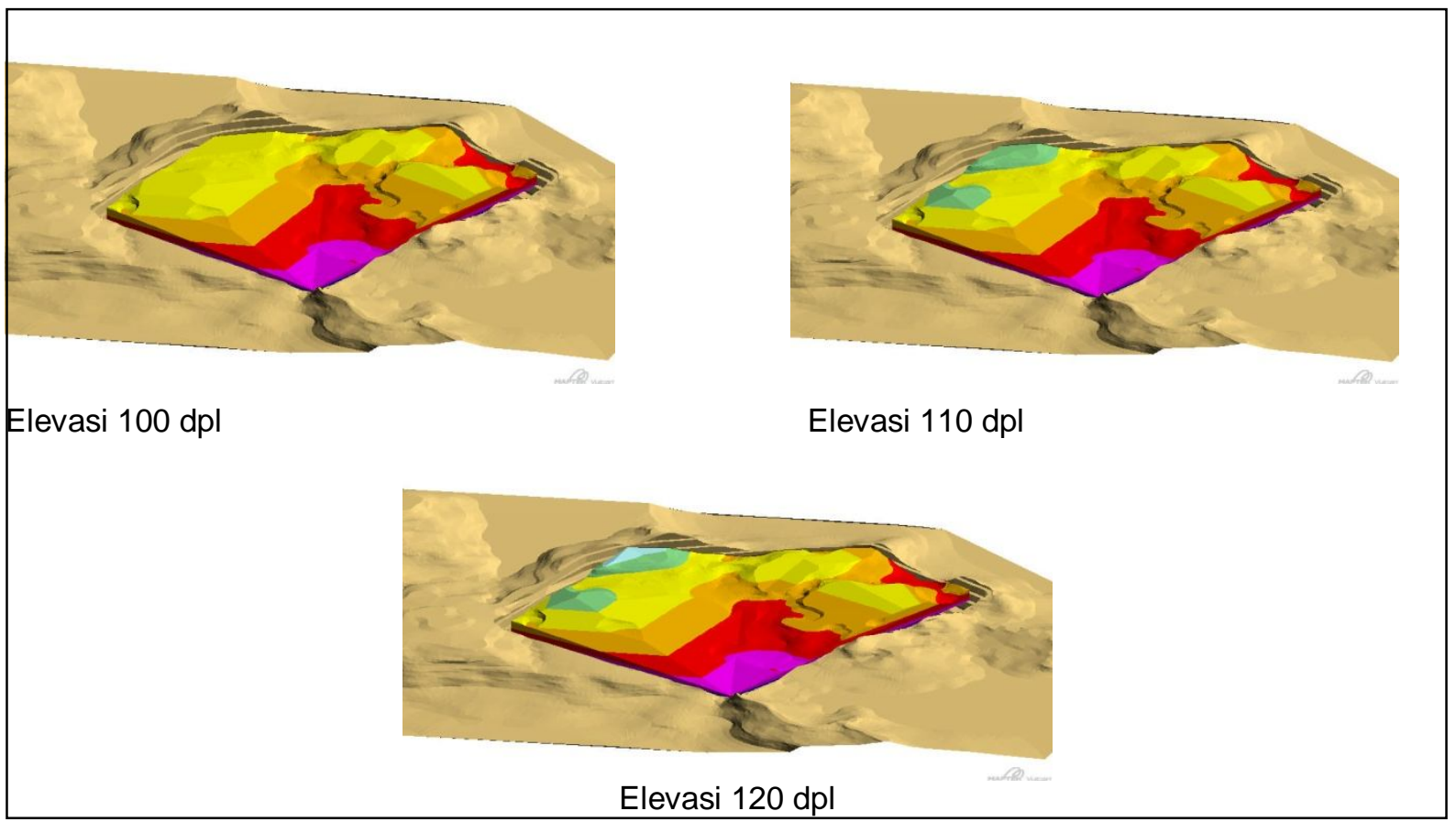

Gambar 4. 9 Model cadangan batugamping pada elevasi $100 \mathrm{dpl}$ sampai $120 \mathrm{dpl}$.

\section{Kesimpulan}

1) Model geologi daerah penelitian terdiri daritiga satuan litologi, yaitu satuan litologi Batugamping, Batulempung, serta Batupasir, Litologi batugamping secara mineralogi dapat diklasifikasikan menurut Duham (1962) menjadi tiga jenis yaitu mudstone, packstone, wackstone. Berdasarkan jumlah komposisi unsur kimia batuan, batugamping di daerah penelitian mempunyai kualitas yang sangat bagus sebagai bahan baku semen dengan jumlah sumberdaya batugamping sebesar $5.730 .000 \mathrm{~m}^{3}$ atau 13.180 .000 ton.
Berdasarkan hasil pengujian dan perhitungan sifat fisik dan mekanik batuan, model rockmass yang dihasilkan menunjukkan bahwa batuan termasuk dalam kategori poor rock-good rock, sehingga model geoteknik yang didapat mempunyai nilai GSI sebesar 24-85.

2) Hasil analisis kestabilan lereng didapat nilai faktor keamanan (FK) relatif stabil dengan nilai FK minimum 1.8. Dalam analisis dilakukan simulasi terhadap tiga model dengan geometri sudut lereng tunggal dan lebar jenjang yang berbeda serta pada tinggi lereng yang sama yaitu10 meter. Sudut lereng 
yang digunakan yaitu : 60 derajat, 70 derajat, dan 80 derajat, serta lebar jenjang masingmasing 4.33 meter, 6.45 meter, dan 8.31 meter, sehingga berdasarkan analisis tersebut geometri lereng yang dapat direkomendasikan untuk desain pit tambang yaitu : sudut lereng tunggal 80 derajat, tinggi jenjang 10 meter, lebar jenjang 8.13 meter, overall slope 54 derajat, dengan kedalaman pit maksimal sebesar 80 meter, dan untuk lebar jalan tambang menggunakan nilai asumsi yaitu sebesar 12 meter.

3) Model cadangan batugamping dibuat per elevasi kemajuan tambang atau berdasarkan tinggi jenjang penambangan yaitu sebesar 10 meter. Elevasi tertinggi disesuaikanterhadap ketinggian maksimum kontur topografi yaitu dimulai pada ketinggian $120 \mathrm{~m}, 110 \mathrm{~m}, 100 \mathrm{~m}$, $90 \mathrm{~m}, 80 \mathrm{~m}, 70 \mathrm{~m}, 60 \mathrm{~m}, 50 \mathrm{~m}$, hingga pada elevasi paling bawah (pit bottom) $40 \mathrm{~m}$, sehingga dari desain pit yang dihasilkan estimasi cadangan batugamping yang dapat dihitung sebesar $2.990 .000 \mathrm{~m}^{3}$ atau 7.477.000 ton.

\section{Daftar Pustaka}

Al-Fajar, A., Huda, L.K., Ramadhan, S., and Husain L, R., 2017, Analisis Kestabilan Lereng Daerah Gattareng Kecamatan Marioriwawo Kabupaten Soppeng Provinsi Sulawesi Selatan., in Prosiding Seminar Nasional Kebumian Ke-10, Grha Sabha Pramana, Universitas Gadjah Mada, Yogyakarta., p. 243251.

Bieniawski, Z.T., 1989, Engineering Rock Mass Classifications, A Complete Manual for Engineers and Geologists in Mining, Civil and Petroleum Engineering: Canada, John Wiley \& Sons, Inc.

Djuri, M., Samodra, H., Amin, T.C., and Gafoer, S., 1996, Peta Geologi Bersistem, Indonesia. Lembar Purwokerto \& Tegal: Pusat Penelitian dan Pengembangan Geologi, Bandung.

Dwiyuniarto, H., 2011, Evaluasi Kuantitatif Massa Batuan Berdasarkan Klasifikasi Geomekanik Dan Geological Strength Index Pada Penambangan Batugamping Dolomit, Studi Kasus Kecamatan Semanding, Kabupaten Tuban, Propinsi Jawa Timur. [Tesis]: Universitas Gadjah Mada.

Gonzales de Vallejo, L. I, and Ferrer, M., 2011, Geological Engineering: Taylor \& Francis Group, London, UK.

Hudson, J.A., and Harrison, J.P., 1997, Engineering Rock Mechanics, An Introduction to the Principles: Elsevier Ltd.

Hustrulid, W., Kuchta, M., and Martin, R., 2013, OPEN PIT MINE Planning \& Design: Taylor \&
Francis Group, London, LLC, 3rd Edition, v. I Fundamentals.

Matthews, M., Simons, N., and Menzies, B., 2008, A Short Course in Geology for Civil Engineers: Thomas Telford Publishing, First publish.

Novrinda, R., and Saputra, I., 2016, Analisis Kemantapan Lereng Kuari Batugamping di Tuban II PT . United Tractors Semen Gresik Tuban Jawa Timur, in Prosiding Seminar Nasional XI "Rekayasa Teknologi Industri dan Informasi, p. 100-110.

Palmstrom, A., 1995, RMi - a rock mass characterization system for rock engineering purposes [Desertation]: Department of Geology, Faculty of Mathematic and Natural Sciences, University of Oslo.

Palmstrom, A., and Stille, H., 2015, Rock Engineering: Thomas Telford Limited, Second edition.

Rai, M.A., Kramadibrata, S., and Wattimena, R.K., 2014, Mekanika Batuan: Laboratorium Geomekanika dan Peralatan Tambang - ITB, Penerbit ITB.

Santika, A.W., and Mulyadi, D., 2017, Geokimia Batugamping Daerah Montong, Tuban, Jawa Timur: Jurnal RISET Geologi dan Pertambangan, v. 27, p. 227-238, doi: 10.14203/risetgeotam2017.v27.493.

Soetoto, 2016, Geologi Dasar: Yogyakarta, Penerbit Ombak, Cetakan III.

Stewart, S., 2007, Rock Mass Strength and Deformability of Unweathered Closely Jointed New Zealand Greywacke [Doctoral Thesis]: Department of Civil Engineering University of Canterbury, $472 \mathrm{p}$.

Sulistyana, W., 2010, Perencanaan Tambang: Jurusan Teknik Pertambangan, UPN "Veteran" Yogyakarta, ANUGERAH Print, Edisi Kelima.

Sulistyana, W., and Zulkarnaen, 2013, Perancangan Penambangan Batugamping Untuk Pabrik Semen Di Kabupaten Banyumas Provinsi Jawa Tengah, in Prosiding TPT XXII PERHAPI, p. 167-173.

Van Bemmelen, R.W., 1949, The Geology of Indonesia, General geology of Indonesia and Adjacent Archipelagoes: Martinus Nijhoff Thague, Netherlands, Second edition, v. IA.

Widiarso, D.A., Kusuma, I.A., and Putro F, A., 2017, Penentuan Potensi Sumberdaya Batugamping Sebagai Bahan Baku Semen Daerah Gandu dan Sekitarnya, Kecamatan Bogorejo, Kabupaten Blora, Jawa Tengah: Jurnal TEKNIK Universitas Diponegoro, v. 2, p. 92-98, doi: 10.14710/teknik.v38n2.13213.

Wyllie, D.C., and Mah, C.W., 2004, Rock Slope Engineering Civil and Mining: 4th Edition. 